\title{
Anmerkungen - Notes
}

Im Morgengrauen - At the Crack of Dawn

S. 8: Wagen mit dem roten Anker: der rote Anker war das Firmenzeichen der Wiener Ankerbrotwerke.

P. 9: carts with the red anchor: the red anchor was the logo of the Viennese commercial bakery 'Ankerbrotwerke'.

S. 18: Vorortelinie: Eisenbahnstrecke in Wien, die die Bahnhöfe Hütteldorf und Heiligenstadt verbindet. Heute Teil des U-Bahnnetzes.

rote Scheibe: signalisierte den letzten Wagen eines $\mathrm{Zu}$ ges.

P. 19: suburban line: railway line connecting the stations Hütteldorf and Heiligenstadt. Today part of the underground network.

red disc: indicated the last carriage of a train.

S. 20: Winnetou, Buffalo Bill, Mahdi: Charaktere aus den als Jugendbücher überaus populären Abenteuerromanen von Karl May (1842-1912).

P. 21: Winnetou, Buffalo Bill, Mahdi: characters from the adventure novels by Karl May (1842-1912), which were very popular with adolescent readers.

S. 22: Feldspat, Quarz und Glimmer/die Drei vergeß ich nimmer: auch heute noch bekannter Merkvers für den Granit.

P. 23: Feldspar quartz and mica/these three I will never forget: A rhyme, still well known as a mnemonic for granite. 
S. 26: Vogel Rock: mythischer Vogel von ungeheurer Stärke in arabischen Märchen.

Craquelées: feine Haarrisse in der Glasur von Keramiken.

Stoob: Marktgemeinde im Burgenland, bekannt als Töpferdorf mit der einzigen österreichischen Keramikfachschule.

P. 27: bird Roc: mythical bird of gigantic strength in Arabian tales.

Craquelés: fine fissures in the glaze of ceramic ware. Stoob: place in Burgenland, famous as a potters' village with the only vocational school for ceramics in Austria.

S. 30: spanische Reiter: 5-6 m lange, mobile Barrieren aus kreuzweise um eine Mittelachse angeordneten Holz- oder Metallpfählen mit Stacheldraht umwunden.

P. 31: chevaux de frise 5-6 $\mathrm{m}$ long mobile barriers consisting of iron or wooden spikes arranged $x$-wise around a middle axis and sometimes bound together by barbed wire, used to repel cavalry or crowds.

S. 32: Karoline Traunwieser: 1794-1815, soll das schönste Mädchen Wiens zur Zeit des Wiener Kongresses gewesen sein. Daß Karoline ihrem vermeintlich aus dem Krieg heimkehrenden Verlobten in Fieberträumen entgegengegangen und dabei erfroren sei, ist eine Sage. Sie starb an Lungenschwindsucht in der Stadtwohnung ihrer Mutter in Wien und ist am Kahlenberger Friedhof begraben.

Fürst Carl Josef de Ligne: Charles Joseph Fürst von Ligne (1735-1814), stammt aus niederländischem Adelsgeschlecht, in österreichischen Diensten. Militärexperte (Feldmarschall) und Schriftsteller. Begraben am Kahlenberger Friedhof. 
P. 33: Karoline Traunwieser: $1794-1815$, is said to have been the most beautiful girl of Vienna at the time of the Congress of Vienna. Legend has it that suffering from severe fever she tried to meet her fiancé whom she thought to be returning from the war and froze to death. She actually died of consumption in her mother's flat in Vienna. She is buried at the Kahlenberg cemetery.

Prince Carl Joseph de Ligne: Charles Joseph Prince de Ligne (1735-1814) descendant of an aristocratic family from the Netherlands in Austrian service. Military expert (field marshal) and writer. Buried at the Kahlenberg cemetery.

S. 38: Justizpalast brennt: am 15. Juli 1927 wurde im Zuge eines Massenprotestes gegen das so genannte "Schattendorfer Urteil" (Schandurteil) der Wiener Justizpalast in Brand gesteckt. Es gab insgesamt 94 Tote und Hunderte Verletzte.

P. 39: Palace of Justice is on fire: on $15^{\text {th }}$ July 1927 the Palace of Justice (the residence of all Vienna based courts and tribunals) was set alight during a mass protest against the so called "Schattendorf judgement". Altogether 94 people were killed and hundreds injured.

S. 40: Schandurteil: am 30. Januar 1927 veranstalteten die Sozialdemokraten in dem kleinen Ort Schattendorf im Burgenland eine Kundgebung, die von kaisertreuen Frontkämpfern beschossen wurde. Es gab zwei Tote, darunter ein achtjähriges Kind und fünf Verletzte. Die Täter wurden von einem Geschworenengericht freigesprochen, was als "Schandurteil" betrachtet wurde und zu gewalttätigen Protesten führte.

P. 41: miscarriage of justice: on $30^{\text {th }}$ January 1927 the Social Democrat Party held a rally in the small village of Schattendorf in the Burgenland. They were fired at by members of the Association of Monarchist War Veterans. 
There were two people killed (one of whom was an eight-year old child) and five injured. The offenders were acquitted by a jury, which was regarded as a miscarriage of justice and led to violent demonstrations.

Fundstücke in einer alten Kommode auf meinem Speicher - Found in a Dresser in my Attic

S. 54: Lieder der Haselnuß: das Motiv des schwarzbraunen Mädchens (Haselnuß) findet sich in vielen Volkslieder seit dem 16. Jh.

Vom gelben Wagen: das bekannte Volkslied "Hoch auf dem gelben Wagen", Text Rudolf Baumbach (1840-1905), wurde 1922 von Heinz Höhne (1892-1968) komponiert.

Wie man Hostien hält: Verweis auf Rainer Maria Rilkes (1875-1926) Die Weise vom Leben und Tod des Cornets Christoph Rilke (1906). Das Zitat lautet: "Als ob man eine Hostie bricht."

P. 55: songs of the hazel nut: the motif of the black-brown girl (hazelnut) can be found in many folk songs since the $16^{\text {th }}$ century.

Yellow wagon: well-known folksong "Hoch auf dem gelben Wagen"(Top of the Yellow Wagon), text by Rudolf Baumbach (1840-1905), was composed by Heinz Höhne in 1922.

As the host is held: reference to Rainer Maria Rilke's (1875-1926) Die Weise vom Leben und Tod des Cornets Christoph Rilke (1906). The actual quotation reads: "As one would breake a consecrated wafer."

S. 56: Starez: Mönch der Ostkirche, meist Einsiedler.

P. 57: Sarets: monk of the Eastern Church, usually a hermit. 
S. 58: Lied vom Guten Kameraden: "Ich hatt einen Kameraden", Text von Ludwig Uhland (1787-1862), Melodie aus dem 18. Jh. anon. Seit 1871 ist das Lied Teil von militärischen Trauerfeierlichkeiten.

Kaffeemühle: Fliegerjargon für Flugzeug.

Faules Ei: gemeint ist hier eine Bombe.

P. 59: Song of the Good Comrade: "Ich hatt einen Kameraden" (I had a comrade), text by Ludwig Uhland (17871862 ), melody from the $18^{\text {th }}$ century anon. Since 1871 the song has been part of military funeral ceremonies.

"Coffee mill": pilot's slang for airplane. rotten egg: refers here to a bomb.

S. 64: Aber rot ist die Heide, eh' sie verblüht: eine Anspielung auf das Gedicht "Das Geheimnis" von Hermann Löns (1866-1914): "Ja grün ist die Heide..."

P. 65: But red is the heath before it withers: reference to the poem "Das Geheimnis" (The secret) by Hermann Löns (1866-1914): "But green is the heath..."

S. 72: Schwestern, Brüder unterm Sternenzelt: Verweis auf Friedrich Schillers Ode An die Freude (1785): Brüder, überm Sternenzelt/Muß ein lieber Vater wohnen!

P. 73: sisters, brothers under the canopy of stars: reference to Friedrich Schiller's ode To Joy (1785): Brothers, above the canopy of stars/Must a loving Father reside.

Fährten legen - Laying Tracks

S. 82: Kärnten und Steiermark: die alliierten Bombergeschwader flogen Wien über Kärnten und Steiermark an. 
Kuckuck: Der Ruf des Kuckucks wurde im Radio als Vorwarnsystem für anfliegende Bomberverbände benützt.

Volksempfänger: billiger, daher für jedermann erschwinglicher in Massenproduktion hergestellter Rundfunkempfänger, der den Empfang ausländischer Stationen nicht zulies. Es lag im Interesse der nationalsozialistischen Regierung, die über den Rundfunk ihre Propaganda verbreitete, daß jedermann ein solches Gerät besitzen, aber damit keine ausländischen Stationen empfangen konnte.

P. 83: Carinthia and Styria: the allied bombing squadrons usually approached Vienna via Carinthia and Styria.

Cuckoo: the cry of the cuckoo was used in the radio to forewarn people of approaching bombing squadrons.

Volksempfänger: a mass-produced, cheap, therefore generally affordable radio, which did not allow the reception of foreign radio stations. It was in the interest of the Nazi-government, which used the radio for propaganda purposes, that everyone should own such an appliance but not be able to listen to foreign radio stations with it.

S. 88: Geschichten aus dem Wienerwald: Titel eines populären Konzertwalzers von Johann Strauß Sohn (1868). In Anspielung darauf schrieb der österreichische Dramatiker Ödön von Horváth ein Stück Geschichten aus dem Wiener Wald (1931)

Prater: Öffentlicher Park und Vergnügungsstätte (Wurstelprater) im 2. Wiener Gemeindebezirk.

Stern: gemeint ist der Praterstern, ein Platz am Beginn des Praters, in den sieben Straßen münden. In der Mitte des Pratersterns befindet sich das Denkmal des Admirals Wilhelm von Tegetthoff, des Siegers der Seeschlacht von Lissa (1866). 
Lusthaus: traditionsreiches Kaffee und Restaurant im Wiener Prater am Ende der Hauptallee, die vom Praterstern zum Lusthaus führt.

Sieger von Lissa: Admiral Wilhelm von Tegetthoff (siehe: Anmerkung zu ,Stern').

Rotenturmtor: Torbau der mittelalterlichen Wiener Stadtmauer nach dem Norden der Stadt.

P. 89: Tales of the Vienna Woods: title of a popular concert waltz by Johann Strauß jun. (1868). With reference to this waltz the Austrian playwright Ödön von Horváth wrote a play called Tales of the Vienna Woods (1931).

Prater: public park and amusement park (Wurstelprater) situated in the $2^{\text {nd }}$ district of Vienna.

Praterstern: roundabout at the beginning of the Prater with seven exit roads. In the middle of the Praterstern is the monument of admiral Wilhelm von Tegetthoff, the victor of the sea battle of Lissa (1866).

Lusthaus: café and restaurant in the Vienna Prater at the end of the main avenue which leads from the Praterstern to the Lusthaus.

Victor of Lissa: Admiral Wilhelm von Tegetthoff (see note to ,Praterstern')

Rotenturm Gate: northern gate of the mediaeval fortifications which surrounded Vienna.

S. 90: Kapital: gemeint ist das einflußreiche Werk von Karl Marx und Friedrich Engels Das Kapital. 3 Bde 1867-1885. Währing: 19. Wiener Gemeindebezirk.

P. 91: Capital: very influential work by Karl Marx and Friedrich Engels, 3 vols 1867-1885.

Währing: $19^{\text {th }}$ district of Vienna.

S. 92: Die 4 im Jeep: Während der Besatzungszeit (19451955) patrouillierten Militärstreifen bestehend aus je einem Mitglied der vier Besatzungsmächte (Amerikaner, Briten, Russen, Franzosen) die Straßen Wiens. 
P. 93: The 4 in a jeep: during the time of occupation (19451955) military patrols made up of one member of each of the occupying forces (Americans, British, Russian, French) drove through the streets of Vienna.

S. 94: Schitomir: Stadt in der Ukraine.

Dnjepr: Fluß in der Ukraine.

P. 95: Schitomir: city in the Ukraine.

Dnieper: river in the Ukraine.

S. 96: An Gärten wandern sie vorbei...: Zitat aus dem Gedicht "Das Lächeln. Eine Frühlingsballade" aus der Sammlung Herbstfrühling (1909) des österr. Dichters Anton Wildgans (1881-1932).

P. 97: Past gardens they walk ...: quotation from the poem "Das Lächeln. Eine Frühlingsballade" (The Smile. A Springballad) from the collection Herbstfrühling (Autumspring)(1909) by the Austrian poet Anton Wildgans (1881-1932).

S. 98: Kuppel von Steinhof: gemeint ist die Kuppel der von Otto Wagner 1903-1907 erbauten Kirche am Steinhof im 14. Wiener Gemeindebezirk. Es ist eine der berühmtesten Jugendstilkirchen der Welt.

P. 99: dome of Steinhof: one of the most famous art nouveau churches in the world. Built by Otto Wagner between 1903 and 1907 at the Steinhof in the $14^{\text {th }}$ district of Vienna.

S. 102: Enns: Fluß in Österreich, der von nördlich von Steyr bis Mauthausen die Grenze zwischen Oberösterreich und Niederösterreich bildet und somit Grenzfluß zwischen der amerikanischen und russischen Besatzungszone war. 
P. 103: Enns: river in Austria which from the north of Steyr up to Mauthausen forms the border between Upper Austria and Lower Austria and therefore was the demarcation line between the American and Russian occupation zones.

S. 104: Admiral: Verweis auf das Monument Admiral Tegethoffs.

Weigel: Hans Weigel (1908-1991), österr. Schriftsteller und Kritiker, der besonders nach dem Krieg durch seine Anthologie Stimmen der Gegenwart junge Talente förderte.

Schillerplatz: die Akademie der bildenden Künste, die Vogel eine zeitlang besuchte, befindet sich am Schillerplatz in Wien.

P. 105: admiral: reference to the monument of admiral Tegetthoff.

Weigel: Hans Weigel (1908-1991), Austrian writer und critic who especially after the war sponsored young artists through his anthology Stimmen der Gegenwart.

Schillerplatz: the Academy of Fine Arts, which Vogel attended for a while, is situated in Schillerplatz in Vienna.

S. 106: Howorka: möglicherweise Nikolaus Hovorka (1901-1966), österr. Publizist und Herausgeber.

Oberministrant: ein sehr katholischer Bekannter aus einem Freundeskreis Alois Vogels.

Gerhard: Gerhard Fritsch (1924-1969), österr. Schriftsteller.

Friedrich: Friedrich Achleitner (1930- ) öster. Architekt und Schriftsteller.

Otto: Otto Muehl (1925- ), Vertreter des Wiener Aktionismus, ab 1971 vor allem mit der Kommune Friedrichshof in Burgenland befaßt. 1991 Verurteilung wegen sexueller Delikte. Lebt in Portugal.

Lingam: Sanskrit: Phallus. Symbol des indischen Gottes Schiwa. 
Burg: gemeint ist das Wiener Burgtheater.

Ronacher: Varieté und Operettentheater im 1. Wiener Gemeindebezirk, das nach dem 2. Weltkrieg bis 1955 dem ausgebombten Burgtheater als Ausweichbühne diente.

Kräutlerin: Das Theater an der Wien gegenüber des Wiener Naschmarkts mit seinen Obst- und Gemüseständen diente nach dem Krieg bis 1955 der ausgebombten Wiener Staatsoper als Ausweichbühne.

Alban: Alban Berg (1885-1935), österr. Komponist, manchmal auch als "letzter Romantiker" bezeichnet.

Armin: möglicherweise Achim von Arnim (1781-1831), deutscher Dichter der Romantik.

Milo: Milo Dor (1923- ), österr. Schriftsteller.

P. 107: Howorka: possibly Nikolaus Hovorka (1901-1966), Austrian writer and editor.

Head altar server: a very catholic acquaintance from a circle of friends of Alois Vogel's.

Gerhard: Gerhard Fritsch (1924-1969), Austrian writer.

Friedrich: Friedrich Achleitner (1930- ), Austrian architect and writer.

Otto: Otto Muehl (1925- ), representative of Viennese Actionism, from 1971 involved with his commune Friedrichshof in Burgenland. In 1991 he was convicted for sexual misconduct. Lives in Portugal.

lingam: Sanskrit: phallus, symbol of the Indian god Shiva.

Ronacher: Variety and operetta theatre in the $1^{\text {st }}$ district of Vienna, which from 1945-1955 served as substitute stage for the bombed Burgtheater.

Herb woman: The Theater an der Wien, opposite the Viennese Naschmarkt with its fruit and vegetable kiosks served after the war until 1955 as a substitute stage for the bombed Vienna State Opera.

Alban: Alban Berg (1885-1935), Austrian composer, sometimes referred to as the "last Romantic". 
Armin: possibly Achim von Arnim (1781-1831), German poet of the Romantic period.

Milo: Milo Dor (1923- ), Austrian writer.

S. 108: Das andere Gesicht: Titel des ersten Romans Alois Vogels 1959.

Raskolnikoff: Hauptfigur aus Fjodor Dostojewskis Roman Schuld und Sühne (1866).

Schanigarten: österreichischer Ausdruck für Tische und Stühle auf dem Gehsteig oder in einer Fußgängerzone vor einem Kaffee- oder Gasthaus.

Freyung: einer der berühmten Plätze der Wiener Altstadt.

Alfred: Alfred Geßwein (1911-1983), österr. Schriftsteller. Doris: Doris Mühringer (1920- ), österr. Schriftstellerin. Josef: Josef Mayer-Limberg (1911- ), Wiener Dialektdichter.

Meier: Josef Mayer-Limberg. s. oben.

Stadtrat: gemeint ist Dr. Viktor Matejka (1901-1993), der von 1945-1949 Kulturstadtrat in Wien war und wesentlich am kulturellen Wiederaufbau Wiens beteiligt war. Obwohl Kommunist, blieb er kritisch und förderte Künstler aller Richtungen.

P. 109: the other face: Vogel's first novel (1959) was called Das andere Gesicht (The Other Face).

Raskolnikoff: main character in Fyodor Dostoyewsky's novel Crime and Punishment (1866).

Pavement café: the Austrian term for tables and chairs set up on the pavement in front of an inn or cafe is "Schanigarten".

Freyung: one of the famous squares in the city centre of Vienna.

Alfred: Alfred Geßwein (1911-1983), Austrian writer.

Doris: Doris Mühringer (1920- ), Austrian writer.

Josef: Josef Mayer-Limberg (1911- ), Viennese dialect poet.

Meier: Josef Mayer-Limberg, see above. 
City councillor: a reference to Dr Viktor Matejka (19011993) who from 1945-1949 was city councillor in Vienna and responsible for cultural affairs. He contributed significantly to the cultural revival in Vienna. Although a critical communist he supported artists of all persuasions.

S. 110: Adler: Dr. Victor Adler (1852-1918), ab 1889 Vorsitzender der österreichischen Sozialdemokraten.

P. 111: Adler (the name is the same as the word meaning 'eagle'): Dr Victor Adler (1852-1918), from 1889 leader of the Austrian Social Democrats.

S. 114: Longfellows Vers "Jedem Menschen Bruder sein": dieser Vers ist nicht von Lonfellow, sondern erschien als Buchtitel und zugleich letzter Vers des Gedichtes "Psalm des Lebens" in einer mehr als freien Übersetzung einer Auswahl der Gedichte Longfellows von Emmy Klein-Synek 1959 im Wiener Amandus Verlag.

Die 9. Strophe des Gedichtes "Psalm des Lebens", (,A Psalm of Life") lautet in der Übersetzung:

Laß uns wachen, laß uns streben,

Keiner steh für sich allein!

Das heißt Sinn dem Dasein geben,

Jedem Menschen Bruder sein.

und im Original:

Let us, then, be up and doing,

With a heart for any fate;

Still achieving, still pursuing,

Learn to labor and to wait.

P. 115: Longfellows's line: this is strictly speaking not a line by Longfellow but appears as book title and last line of the poem "A Psalm of Life" in a German translation of a selection of Longfellow's poems by Emmy Klein-Synek published in 1959 by Amandus Verlag in Vienna. The $9^{\text {th }}$ stanza of "A Psalm of Life" reads in the original: 
Let us, then, be up and doing,

With a heart for any fate;

Still achieving, still pursuing,

Learn to labor and to wait.

and in translation:

Laß uns wachen, laß uns streben,

Keiner steh für sich allein!

Das heißt Sinn dem Dasein geben, Jedem Menschen Bruder sein.

S. 116: Gänsehäufel: großes, beliebtes Freiluftbad an der Alten Donau im 22. Wiener Gemeindbezirk, das bis zu 30.000 Badegästen Platz bietet.

Florian Berndl: österreichischer Naturheilkundler (18561934), der das heute noch beliebte Freiluftbad Gänsehäufel gründete.

P. 117: Gänsehäufel: large and popular open-air bath at the Old Danube in the $22^{\text {nd }}$ district of Vienna, which can accommodate up to 30,000 people.

Florian Berndl: Austrian naturopath (1856-1934) who founded the open-air bath Gänsehäufel, which is now public and still extremely popular.

S. 124: Parco dell Aventin: der Aventin ist einer der sieben klassischen Hügel Roms.

S. 125: Parco dell Aventin: the Aventin is one the seven classical hills of Rome.

S. 126: Grab der Caecilia Metella: das berühmte zylindrische Grabmal der Caecilia Metella, Tochter des Quintus Caecilius Metllus Creticus, an der Via Appia.

P. 127: tomb of Caecilia Metella: the famous cylindrical tomb of Caecilia Metella, daughter of Quintus Caecilius Metellus Creticus, at the Appian Way. 